\title{
Prevalence of Mycoplasma pneumoniae from Symptomatic Pediatric Patients Referred to a Child Outpatient Clinic of a University Hospital
}

\author{
Bir Üniversite Hastanesinde Çocuk Sağlığı ve Hastalıkları Kliniklerine Başvuran \\ Hastalarda Mycoplasma pneumoniae Sıklığının Araştırılması
}

\author{
Muammer Osman Köksal'(iD), Özge Kaba²(ID), Hayati Beka'(iD), Mustafa Önel'(iD), Manolya Kara(iD), \\ Selda Hançerli Törün²(ID), Sevim Meşe'(iD), Ayper Somer²(iD), Ali Ağaçfidan'(iD) \\ ${ }^{1}$ Department of Medical Microbiology, Istanbul University Istanbul School of Medicine, Istanbul, Turkey \\ ${ }^{2}$ Department of Pediatrics, Istanbul University Istanbul School of Medicine, Istanbul, Turkey \\ ${ }^{3}$ Clinic of Pediatric Infectious Diseases, Kahramanmaras Maternity and Children Hospital, Kahramanmaras, Turkey
}

Cite this article as: Köksal MO, Kaba Ö, Beka H, Önel M, Kara M, Hançerli Törün S, et al. Prevalence of Mycoplasma pneumoniae from symptomatic pediatric patients referred to a child outpatient clinic of a university hospital. J Pediatr Inf 2021;15(1):e1-e6.

\section{Abstract}

Objective: Lower respiratory tract infections are one of the major causes of morbidity and mortality in children worldwide. Besides, epidemiological data on this subject is very limited. Mycoplasma pneumoniae is an important bacterial agent in community-acquired pneumonia (CAP) and may cause mild, moderate and severe lower respiratory tract infections. Clinical diagnosis is very difficult.

Material and Methods: In this study, it was aimed to determine the seroprevalence of $M$. pneumoniae in children aged 0-17 years admitted to a medical faculty in Istanbul with lower respiratory tract complaints or non-respiratory findings such as cytopenia and arthritis/arthralgia and to determine the prevalence of infection among children in various age groups. One hundred and thirty-four patients were included in the present study. Venous blood and nasopharyngeal swab samples were taken from study patients. M. pneumoniae lgG and IgM antibodies were determined by ELISA (Enzyme Liquid Immunoassay) test in blood samples and M. pneumoniae Real-time polymerase chain reaction (RT-PCR) test was performed in nasopharengeal swab samples.

Results: Seropositivity was seen in 50 (37.3\%) patients, only specific lgM antibody positivity in $5(3.7 \%)$ patients, both specific lgM antibody and specific lgG antibody positivity in 8 (6\%) patients and 37 (27.6\%) patients specific IgG antibody was also observed. The number of $M$. pneumoni-
Öz

Giriş: Alt solunum yolu enfeksiyonları tüm dünyada çocuklarda önemli bir morbidite ve mortalite nedeni olup bu konudaki epidemiyolojik veriler oldukça sınırlıdır. Mycoplasma pneumoniae, toplum kökenli pnömonilerde (TKP) önemli bir bakteriyel bir ajandır ve hafif, orta ve ciddi alt solunum yolu enfeksiyonuna neden olabilir. Klinik olarak tanı konması oldukça zordur.

Gereç ve Yöntemler: Bu çalışmada İstanbul'da bir tıp fakültesine alt solunum yolu enfeksiyonu bulguları veya sitopeni ve artrit/artralji gibi solunum dışı bulgularla başvuran 0-17 yaş arası çocuklarda M. pneumoniae seroprevalansını belirlemeyi ve çeşitli yaş gruplarındaki çocuklarda enfeksiyon prevalansının dağılımını tespit etmeyi amaçladık. Çalışmamıza 134 hasta dâhil edilmiştir. Çalışmamıza katılan hastalardan venöz kan ve nazofarengeal sürüntü örnekleri alınmış olup, kan örneklerinde $M$. pneumoniae IgG ve IgM antikorlarının tayini Enzim Likit immunassay (ELISA) testi; nazofarengeal sürüntü örneklerinde ise $M$. pneumoniae gerçek zamanlı polimeraz zincir reaksiyonu (GZ-PZR) testi gerçekleştirilmiştir.

Bulgular: Toplam 50 (\%37.3) hastada seropozitiflik görülmüş olup, 5 (\%3.7) hastada sadece spesifik IgM antikor pozitifliği, 8 (\%6) hastada hem spesifik IgM antikoru hem de spesifik IgG antikoru, 37 (\%27.6) hastamızda da spesifik IgG antikoru gözlemlenmiş̧ir. M. pneumoniae DNA GZ-PZR pozitif örnek sayımız sadece 2 (\%1.5) olarak gösterilmiş olup bu hastaların ikisi de serolojik olarak pozitiflik göstermemiş hastalardır.
Correspondence Address/Yazışma Adresi
Muammer Osman Köksal
İstanbul Üniversitesi İstanbul Tıp Fakültesi,
Tıbbi Mikrobiyoloji Anabilim Dalı,
İstanbul-Türkiye
E-mail: muammerosmankoksal@istanbul.edu.tr

E-mail: muammerosmankoksal@istanbul.edu.tr
Received: $10.12 .2019 \quad$ Accepted: 18.07.202 
ae DNA RT-PCR positive samples was shown to be only 2 (1.5\%), both of which were not serologically positive.

Conclusion: Our results show a significant prevalence of $M$. pneumoniae in children diagnosed with acute respiratory infection. It also highlight the importance of laboratory detection for appropriate and rapid antibiotic treatment.

Keywords: Respiratory tract infection, Mycoplasma pneumoniae, ELISA, RT-PCR

\section{Introduction}

Lower respiratory tract infections (LRTI) are one of the leading causes of morbidity and mortality in children (1). Epidemiological data on LRTI agents is considerably limited in particularly developing countries (2). Mycoplasma pneumoniae is a bacterial agent with increasing importance in community-acquired pneumonia (CAP) worldwide. Its incubation period may last 1-3 weeks. M. pneumoniae infection is transmitted from patients through droplets and usually mild and self-limiting (3). It is a common cause of CAP and other community-acquired lower respiratory tract infections (CAP-LRTI) in especially school-aged children and adolescents $(4,5)$. M. pneumoniae may result in mild, moderate or severe acute respiratory tract infections (6). Its clinical symptoms range from mild tracheobronchitis to severe atypical pneumonia cases and may be followed by a wide range of extrapulmonary complication spectrum (7). Accurate and rapid detection of the infection is of critical significance in initiating appropriate treatment.

It is difficult to clinically confirm M. pneumoniae infection since it is nearly impossible to diagnose this disease based only on clinical signs and symptoms. Therefore, accurate and true diagnosis in order to provide for definitive diagnosis and appropriate treatment and decrease unnecessary antibiotic use of the infected patients is of utmost importance. Laboratory diagnosis of $M$. pneumoniae infections is substantially difficult both because of the requirement to provide special culture conditions for the growth of the agent and the incubation period takes several weeks, which makes clinical practice impossible. Although serological diagnosis is widely used, it can be confusing due to the fact that it gives false negative results particularly in the early acute phase of the infection and serums of the convalescent period cannot be obtained in hospitalizations less than 1 week. The gold standard in the diagnosis of $M$. pneumoniae infections is still a fourfold increase in the antibody titer of sera taken during acute and convalescent periods. (8). Besides, convalescent serum is not useful in clinical practice and does not allow for the clinicians to initiate treatment protocols on time.

Polymerase chain reaction (PCR) stands out as an alternative diagnosis method for etiological agents that are difficult to culture or detect with other methods. PCR is a relatively sensitive and specific diagnostic method for the diagnosis of acute $M$. pneumoniae infections and is used to avoid the risk of false neg-
Sonuç: Sonuçlarımız, akut solunum yolu enfeksiyonu tanısı konan çocuklarda M. pneumoniae sıklığını göstermektedir. Ayrıca uygun ve hızlı antibiyotik tedavisi için laboratuvar tespitinin önemini vurgulamaktadır.

Anahtar Kelimeler: Solunum yolu enfeksiyonu, Mycoplasma pneumoniae, ELISA, GZ-PZR

ative results observed in conventional culture methods (9-11). Combination of PCR and serology is recommended for a safer diagnostic approach. Real-time PCR (RT-PCR) is an accurate, efficient and time-saving method for clinicians due to its very fast results, high specificity and sensitivity. In this study, it was aimed to determine $M$. pneumoniae seroprevalence in children aged 0-17 presenting to a Istanbul University Medical School with lower tract respiratory infection symptoms or non-respiratory findings like cytopenia and arthritis/arthralgia and detect the distribution of infection prevalence in children at various age groups.

\section{Materials and Methods}

Data of a total of 134 patients presenting to the polyclinics of Pediatric Health and Diseases of Istanbul University Medical School between January 2016 and May 2019 with lower respiratory tract findings or non-respiratory findings like cytopenia and arthritis/arthralgia were retrospectively reviewed. During the acute phase of the disease, venous blood and nasopharyngeal swab specimens were taken from the patients participating in the study. ELISA test was used to determine IgG and IgM antibodies of $M$. pneumoniae in blood samples, and real-time PCR (RT-PCR) was used to study M. pneumoniae from nasopharyngeal specimens. Patients in whom only ELISA or RT-PCR tests was performed were excluded from the study.

1-2 $\mathrm{mL}$ blood samples taken into dry blood tubes were centrifuged for 5 minutes at $5000 \mathrm{rpm}$, and suitable samples were included into the study after having checked all for coagulum, hemolysis and lipemia. For M. pneumoniae $\operatorname{lgM}$ and IgG ELISA test (Vircell, Granada, Spain), patient samples were placed onto Triturus Automatic Microeliza system (Grifols, Barcelona, Spain). Serum samples diluted at a rate of 1:11 with dilution tampon were added to the study well. The study was performed on the Triturus Automatic Microeliza system in line with the manufacturer's instructions. Patient values were read on the spectrophotometer with a $450 \mathrm{~nm}$ reference absorbance value, and evaluations were made based on calibrator samples and in line with the manufacturer's instructions. For the presence of $M$. pneumoniae infection, patients with an antibody index of 0.9 or lower and of 1.3 and higher were considered negative and positive respectively, and patients with an index value between 0.9-1.3 were assessed as gray zone. 
Table 1. Distribution of clinical findings and laboratory results according to age groups

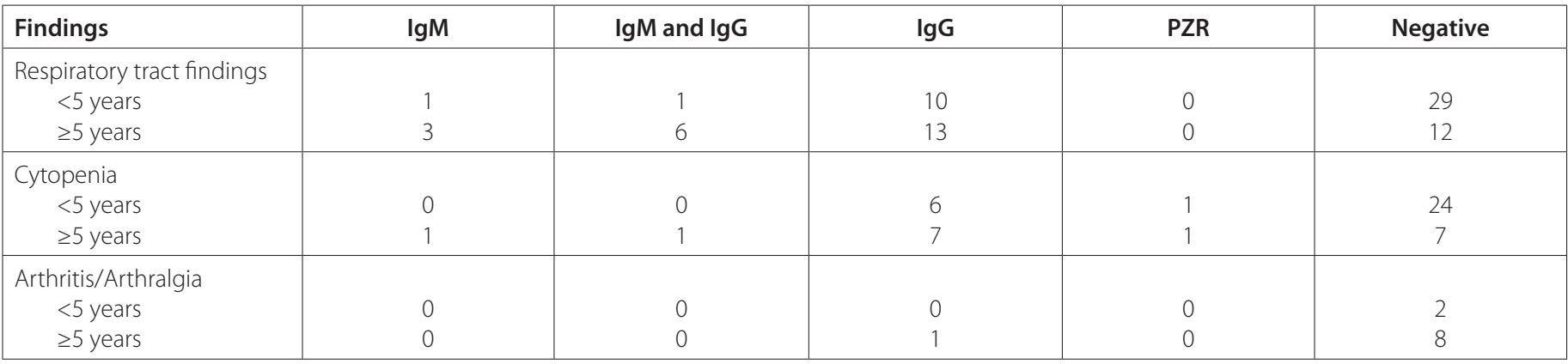

Table 2. M. pneumoniae seroprevalence according to age and sex

\begin{tabular}{|l|c|c|c|c|c|c|c|c|}
\hline & $\lg M(+)$ & $\operatorname{lgM}(-)$ & Chi-square & $\mathbf{p}$ & IgG (+) & IgG (-) & Chi-square & p \\
\hline$<5$ years & $2(7.18)$ & $72(66.82)$ & 9.24 & 0.0023 & $15(24.85)$ & $59(49.15)$ & 13.13 & 0.0002 \\
$\geq 5$ years & $11(5.82)$ & $49(54.18)$ & & & $30(20.15)$ & $30(39.85)$ & \\
\hline Girl & $10(5.34)$ & $45(49.66)$ & 7.65 & 0.0056 & $18(18.47)$ & $37(36.53)$ & 0.03 & 0.86 \\
Boy & $3(7.66)$ & $76(71.34)$ & & & $27(26.53)$ & $52(52.47)$ & \\
\hline
\end{tabular}

Nasopharyngeal swab specimens were taken into the transportation liquid (Medical Wire\&Equipment, Wiltshire, England). It was provided for the sample material of the samples taken into the transportation liquid with swabs to be dissolved in the transportation liquid, and 400 microliters sample DNA isolation taken from the liquid was achieved in line with the manufacturer's instructions on Qiagen EZ1 Advanced XL automated nucleic acid device (Qiagene, Hilden, Germany) using the Qiagen-EZ1 Virus Mini kit (Qiagene, Hilden, Germany). The DNA samples obtained were applied with RT-PCR on Rotor-Gene Q (Qiagen, Australia) device using the FTD Respiratory Pathogens $21^{\circledast}$ (Fast-Track Diagnostics, Luxembourg) kit. Some viral agents other than B M. pneumoniae can also be detected by this test. $10 \mu \mathrm{L}$ isolated nucleic acid was put into the $15 \mu \mathrm{L}$ reaction mixture. RT-PCR condition is 10 minutes at $50^{\circ} \mathrm{C}, 1$ minute at $94^{\circ} \mathrm{C}, 8$ seconds at 40 cycles $94^{\circ} \mathrm{C}$, and 1 minute at $60^{\circ} \mathrm{C}$. RT-PCR was performed according to the manufacturer's instructions.

Statistical analyses were done on SPSS (Statistical Package for the Social Sciences) 21.0 program. In order to test the rate difference between qualitative variables, Chi-square test and Fisher's Exact test were used. Statistical significance was set at $\mathrm{P}<0.05$.

\section{Results}

Seventy-four (55.2\%) of a total of 134 patients included in our study comprised of children younger than 5 years. Our sample group included $80(59.7 \%)$ boys and $54(40.3 \%)$ girls. In 34 (25.4\%) of the 75 patients detected to have lower respiratory tract infection as a result of hospital presentation, $\operatorname{lgM}$ $(n=4), \lg G(n=22)$ or $\lg M$ and $\lg G(n=7)$ positivity was deter- mined. In 17 (12.7\%) of the 48 patients detected to have cytopenia, $\lg M(n=1), \lg G(n=13), \lg M$ and $\lg G(n=1)$ or RT-PCR positivity was confirmed. In 11 (0.7\%) patients detected having arthritis/arthralgia, IgG positivity was detected (Table 1). When serologic findings of the cases were evaluated, seropositivity was seen in 50 patients (37.3\%), specific IgM antibody positivity, specific lgM and specific lgG antibody, and specific IgG antibody were observed in 5 (3.7\%), 8 (6\%) and 37 (27.6\%) patients, respectively. Positive number of $M$. pneumoniae RTPCR cases was only $2(1.5 \%)$, and both of these patients did not show positivity serologically. M. pneumoniae RT-PCR result was obtained negative in 5 patients whose specific lgM antibody was positive. Two of the patients with M. pneumoniae IgM positivity were aged under 5 years and 11 of them were aged over 5 . When children aged under and over 5 years were compared, a significant difference was achieved in terms of M. pneumoniae infection $(p=0.002)$. Moreover, when significance was compared depending on the sexes, a significant difference was not found in the general prevalence; however, M. pneumoniae IgM antibodies were found significantly higher in girls $(p=0.004)$ (Table 2$)$. It was observed based on our study group that the number of cases with suspected.

\section{Discussion}

M. pneumoniae pneumonia is observed worldwide, and this agent is responsible for $10-40 \%$ of community-acquired pneumonia cases. Nonetheless, information on the epidemiology of these bacteria in Turkey is still limited. In this study conducted to determine prevalence at the age range of 0-17 years, M. pneumoniae antibodies were detected in $37.3 \%$ of the blood samples. In two different studies carried out on children aged under 15 years in Istanbul, M. pneumoniae pos- 


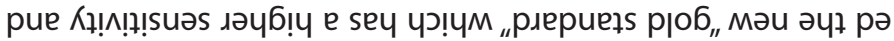

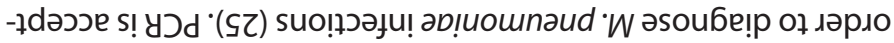

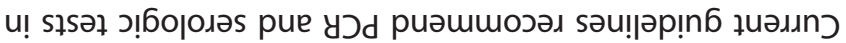

-ab!uounaud

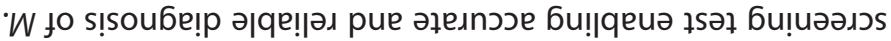
poo6 e se pəsn әq ueว ' $К$ бо

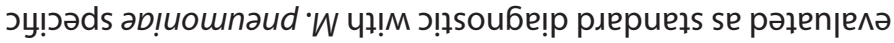

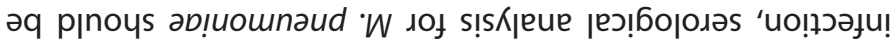

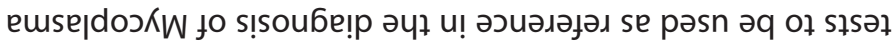

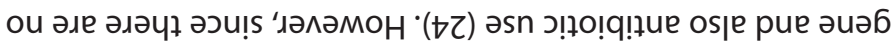

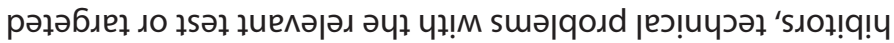

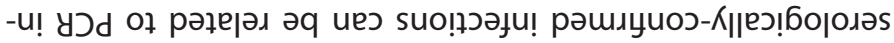

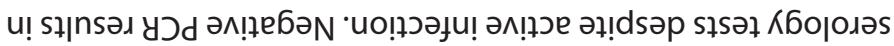

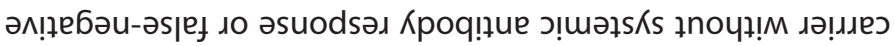

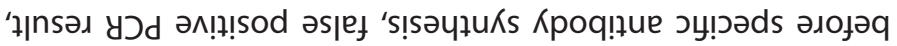

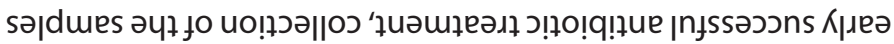

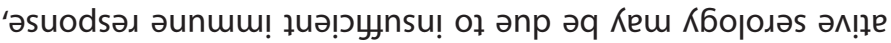

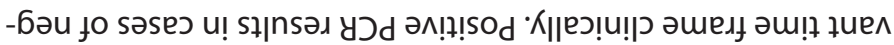
-әрә е и! лә!ג

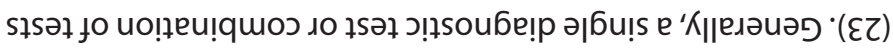

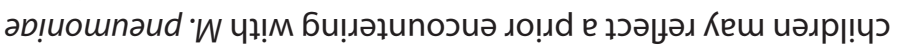

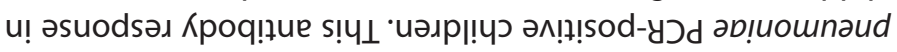

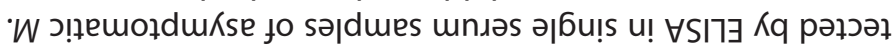

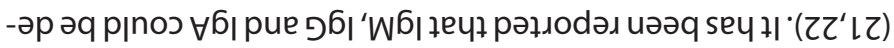

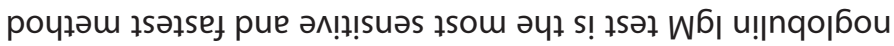

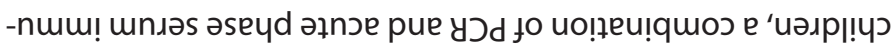
u! e!̣uouñud ap! uounaud ' $W$ әsouбe!

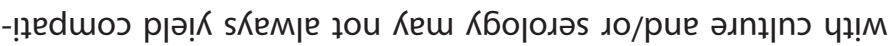

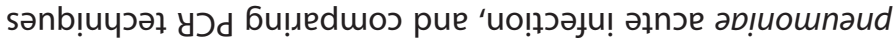

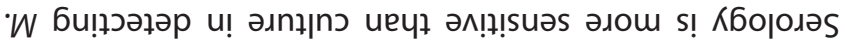

syzuom

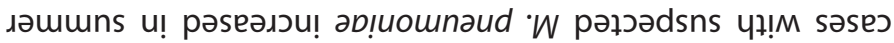

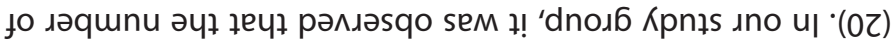
ınวכо sग!щәр!

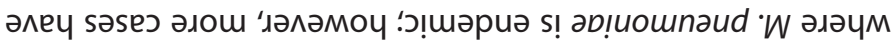

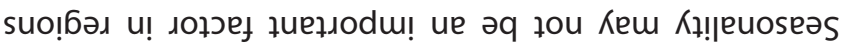

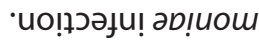

-naud ' $W$ fо әэиәр!

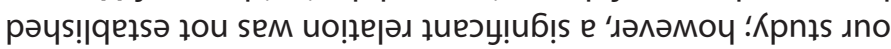

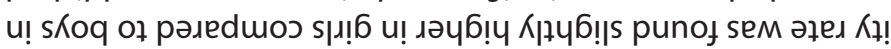

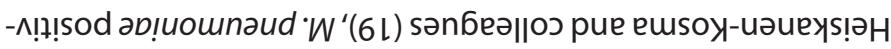

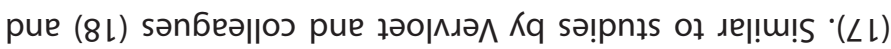

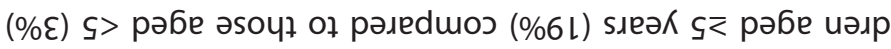

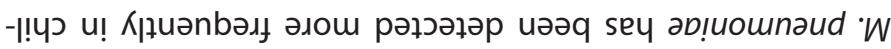

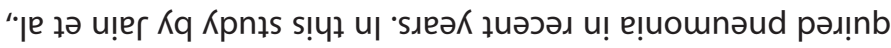

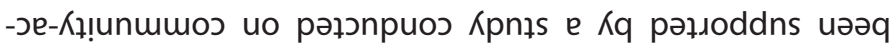
sеч

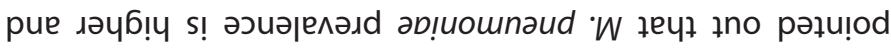

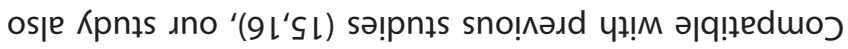

•(8) иәлр!!чว u! IL४า рәג!nb

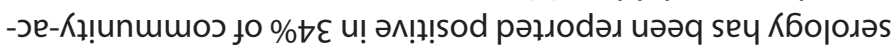

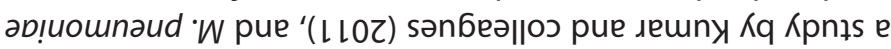

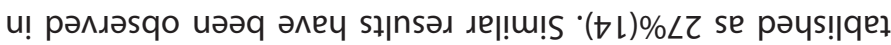

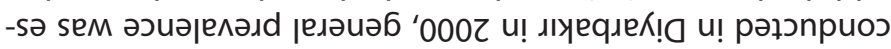

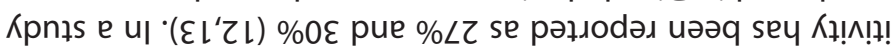

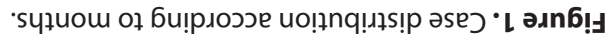

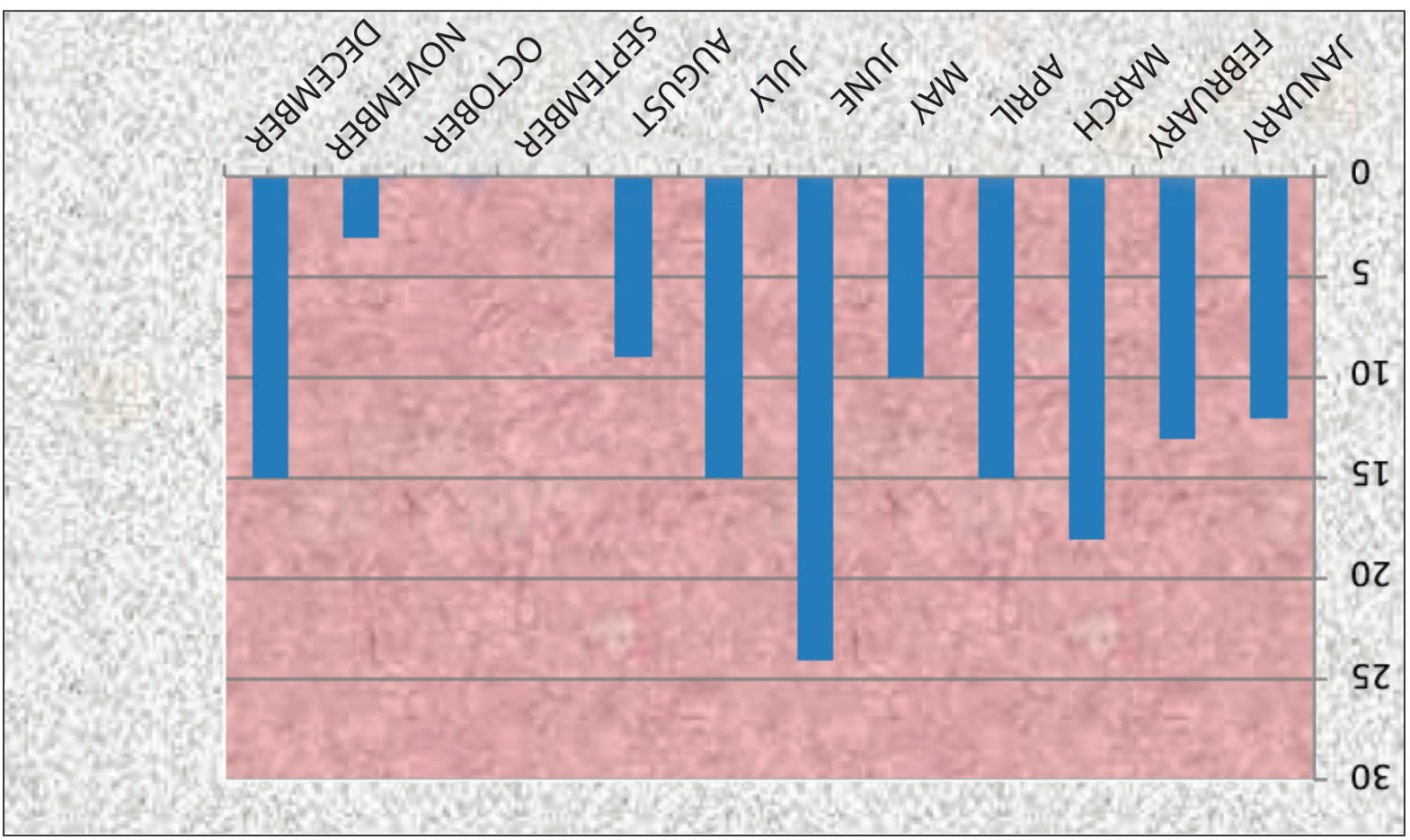


shorter time frame than culture (26). As in many other respiratory pathogens, M. pneumoniae can be carried in the upper respiratory tract of asymptomatic children. Detection rates in children without symptoms of respiratory tract infection changes between 3-56\%, which implies that the presence of M. pneumoniae alone may not show definite respiratory tract diseases in respiratory tract infections $(17,21,23)$.

The gold standard method of $M$. pneumoniae infection is the fourfold increase in $M$. pneumoniae specific lgG related to the comparison of acute phase and convalescent serums collected with 2-4 weeks interval. The need for convalescent serum sample means that the gold standard can only be used retrospectively and is not useful in clinical practice. Using only acute phase serology seems lacking in sensitivity and specifity. In our study, the low compatibility between PCR and serology may have resulted due to above-mentioned reasons; and moreover, despite being accepted as the appropriate sample, it is seen that nose swab materials and throat swab are insufficient in detecting the agent that locates in lower respiratory tract and causes infection. There are studies on the diagnosis of this agent in bronchoalveolar lavage samples (27). It is evident that studies comparing samples and methods are needed to find the reference standard.

Our results show prevalence of $M$. pneumoniae infections in children diagnosed with acute respiratory tract infection and emphasize the significance of laboratory detection for appropriate, rapid and accurate antibiotic treatment. M. pneumoniae is a crucial health problem, especially in children. In our country, limitations in diagnosis in the past had prevented us from understanding the epidemiology of local epidemic environment and spread of this pathogen.

Limited number of cases, retrospective nature of the study, and not having evaluated the amount of antibody increase due to the fact that specific IgG antibodies in the cases were not collected within 2-10 weeks following the increase are the limitations of our study. Nonetheless, the study is significant in investigating regional data aimed at diagnosing M. pneumoniae infections.

\section{Conclusion}

To conclude, there is no test that definitely differentiates $M$. pneumoniae infection from the carrier or from a prior M. pneumoniae infection. Clinician is the person to solve this dilemma. The physician should try to make a diagnosis considering the abovementioned limitations and patients' clinical characteristics. In addition, a national surveillance program should be established for atypical pneumonia etiologies in our country, and RT-PCR use should be evaluated as a reliable diagnostic method with further studies.
Ethics Committe Approval: The approval for this study was obtained from Istanbul University, Istanbul School of Medicine Ethics Committee (Decision no: 1546/2019 Date: 2019).

Informed Consent: Patient consent was obtained.

Peer-review: Externally peer-reviewed.

Author Contributions: Concept - MOK ,ÖK, MK, AA, AS; Design - MOK, ÖK, MK, AA, AS; Supervision -SHT, SM; Resource - MOK, ÖK; Data Collection and/or Processing - MOK, ÖK, HB, MÖ; Analysis and/ or Interpretation -MOK, ÖK ,HB, MÖ; Literature Search - MOK, HB, MÖ, SM; Writing - MOK, ÖK, MK, SHT; Critical Review - AA, AS, SM, SHT.

Conflict of Interest: Authors declared no conflict of interest.

Financial Disclosure: The authors declared that this study has received no financial support.

\section{References}

1. Mathew J, Singhi S, Ray P, Hagel E, Saghafian-Hedengren S, Bansal A, et al. Etiology of community acquired pneumonia among children in India: prospective, cohort study. J Glob Health 2015;5(2):050418 [CrossRef]

2. Grassi T, Mancini F, Ciervo A, Vescio MF, Ghazal A, Ashour H, et al. Chlamydophila pneumoniae, Mycoplasma pneumoniae, and influen$z a$ in children with respiratory infections in Alexandria, Egypt. $J$ Infect Dev Ctries 2014;8(3):379-83. [CrossRef]

3. HuongPle T, Hien PT, Lan NT, Binh TQ, Tuan DM, Anh DD. First report on prevalence and risk factors of severe atypical pneumonia in Vietnamese children aged $1 \pm 15$ years. BMC Public Health 2014;14:1304. [CrossRef]

4. Bradley JS, Byington CL, Shah SS, Alverson B, Carter ER, Harrison C, et al. The management of community-acquired pneumonia in infants and children older than 3 months of age: clinical practice guidelines by the Pediatric Infectious Diseases Society and the Infectious Diseases Society of America. Clin Infect Dis 2011;53(7):e25-76. [CrossRef]

5. Shah SS, Test M, Sheffler-Collins S, Weiss AK, Hall M. Macrolide therapy and outcomes in a multicenter cohort of children hospitalized with Mycoplasma pneumoniae pneumonia. J Hosp Med 2012;7(4):311-7. [CrossRef]

6. Chen Z, Ji W, Wang Y, Zhu H, Shao X, Xu J. Epidemiology and associations with climatic conditions of Mycoplasma pneumoniae and Chlamydophila pneumoniae infections among Chinese children hospitalized with acute respiratory infections. Ital J Pediatr 2013 May 25;39:34. [CrossRef]

7. Song $Q, X u B$, Shen K. Effects of bacterial and viral co-infections of Mycoplasma pneumoniae pneumonia in children: analysis report from Beijing Children's Hospital between 2010 and 2014. Int J Clin Exp Med 2015;8(9):15666-74. [CrossRef]

8. Kumar S, Saigal SR, Sethi GR. Rapid diagnosis of Mycoplasma pneumoniae by polymerase chain reaction in community-acquired lower respiratory tract infections. Trop Doct 2011;41:160-2. [CrossRef]

9. Huong $P$, Hien $P$, Lan N, Binh TQ, Tuan DM, Anh DD. pneumonia in vietnamese children aged 1 to 15 years due to atypical pneumonia causative bacteria: hospital-based microbiological and epidemiological characteristics. Jpn J Infect Dis 2014;14:1304. [CrossRef] 
10. Beersma M, Dirven K, van Dam A, Templeton KE, Claas EC, Goossens $H$. Evaluation of 12 commercial tests and the complement fixation test for Mycoplasma pneumoniae-specific immunoglobulin G (IgG) and IgM antibodies, with PCR used as the "gold standard". J Clin Microbiol 2005;43(5):2277-85. [CrossRef]

11. Blystad H, Ånestad G, Vestrheim D, Madsen S, Ronning K. Increased incidence of Mycoplasma pneumoniae infection in Norway 2011. Euro Surveill 2012;17(5):20074. [CrossRef]

12. Somer A, Salman N, Yalçin I, Ağaçfidan A. Role of Mycoplasma pneumoniae and Chlamydia pneumoniae in children with community-acquired pneumonia in Istanbul, Turkey. J Trop Pediatr 2006;52(3):173-8. [CrossRef]

13. Sidal M, Kilic A, Unuvar E, Oguz F, Onel M, Agacfidan A et al. Frequency of Chlamydia pneumoniae and Mycoplasma pneumoniae infections in children. J Trop Pediatr 2007;53(4):225-31. [CrossRef]

14. Bosnak M, Dikici B, Bosnak V, Dogru O, Ozkan I, Ceylan A et al. Prevalence of Mycoplasma pneumoniae in children in Diyarbakir, the southeast of Turkey. Pediatr Int 2002;44(5):510-2. [CrossRef]

15. Waites KB, Talkington DF. Mycoplasma pneumoniae and its role as a human pathogen. Clin Microbiol Rev 2004;17:697-728. [CrossRef]

16. Waris ME, Toikka P, Saarinen T. Diagnosis of Mycoplasma pneumoniae pneumonia in children. J Clin Microbiol 1998;36:3155-9. [CrossRef]

17. Jain S, Williams DJ, Arnold SR, Ampofo K, Bramley AM, Reed C, et al.; CDC EPIC Study Team. Community-acquired pneumonia requiring hospitalization among US. children. N Engl J Med 2015;372:835-45. [CrossRef]

18. Vervloet LA, Camargos PAM, Soares DRF, De Oliveira GA, De Oliveira JN. Clinical, radiographic and haematological characterstics of Mycoplasma pnumoniae pneumonia. J Pediatr 2010;86(6):480-7. [CrossRef]

19. Heiskanen-Kosma T, Korppi M, Jokinen C, Kurki S, Heiskanen L, Juvonen $H$ et al. Etiology of childhood pneumonia: serologic results of a prospective, population based study. Pediatr Infect Dis J 1998;17:986-91. [CrossRef]
20. Onuzuka D, Hashizume $M$, Hagihara A. Impact of weather factors on Mycoplasma pneumoniae pneumonia. Thorax 2009;64:507-11. [CrossRef]

21. Waites KB, Xiao L, Liu Y, Balish MF, Atkinson TP. Mycoplasma pneumonia from the respiratory tract and beyond. Clin Microbiol Rev 2017;30:747809. [CrossRef]

22. Petitjean-Lecherbonnier J, Vabret A, Gouarin S, Dina J, Legrand L, Freymuth F. Mycoplasma pneumoniae infections: retrospective study in Basse-Normandie, 1997-2005, epidemiology-diagnostic utility of serology and PCR for a rapid diagnostic. Pathol Biol 2006;54:603-11. [CrossRef]

23. Spuesens EB, Fraaij PL, Visser EG, Hoogenboezem T, Hop WC, van Adrichem $L N$, et al. Carriage of Mycoplasma pneumoniae in the upper respiratory tract of symptomatic and asymptomatic children: an observational study. PLoS Med 2013;10:e1001444. [CrossRef]

24. Atkinson TP, Balish MF, Waites KB. Epidemiology, clinical manifestations, pathogenesis and laboratory detection of Mycoplasma pneumoniae infections. FEMS Microbiol Rev 2008;32:956-73. [CrossRef]

25. Yin YD, Zhao F, Ren LL, Song SF, Liu YM, Zhang JZ, et al. Evaluation of the Japanese Respiratory Society guidelines for the identification of Mycoplasma pneumoniae pneumonia. Respirology 2012;17(7):1131-6. [CrossRef]

26. Loens K, leven M. Mycoplasma pneumoniae: Current knowledge on nucleic acid amplification techniques and serological diagnostics. Front Microbiol 2016;7:448. [CrossRef]

27. Schmitt BH, Sloan LM, Patel R. Real-time PCR detection of Mycoplasma pneumoniae in respiratory specimens. Diagn Microbiol Infect Dis 2013;77(3):202-5. [CrossRef] 